\title{
CCR6 wt Allele
}

National Cancer Institute

\section{Source}

National Cancer Institute. CCR6 wt Allele. NCI Thesaurus. Code C51323.

Human CCR6 wild-type allele is located within $6 \mathrm{q} 27$ and is approximately $16 \mathrm{~kb}$ in length.

This allele, which encodes C-C chemokine receptor type 6 protein, is involved in B-cell

maturation and antigen-driven B-cell differentiation. The allele may also regulate the

migration and recruitment of dentritic and T cells during inflammatory and immunological responses. 